\title{
SOCIAL WELL-BEING OF THE POPULATION OF THE BORDER RUSSIAN REGION IN TERMS OF HUMANITARIAN CHALLENGES (THE EXAMPLE OF THE ROSTOV REGION)
}

\author{
Anton Vladimirovich Serikov ${ }^{1}$, Andrey Vladimirovich Bedrik ${ }^{2}$, \\ Yulia Sergeevna Panfilova ${ }^{3}$
}

\begin{abstract}
The issues related to the study of social well-being of the population are presented in terms of the humanitarian challenges experienced in Russian regions. The paper identifies the latent sources of social tension with the border regions classified as high-risk areas of special research interest. In this article, the authors identify and analyze the main components affecting the well-being of the population in the Rostov region, a border region of Russia, from a macrosocial perspective. The empirical basis for the work includes the materials of sociological research conducted by scientists of the Southern Federal University and the South Russian Branch of the Federal Research Sociological Center of the Russian Academy of Sciences in 2013-2017. Based on the results of the empirical measurements, the authors propose that an increase in the population's overall level of social well-being is vital in forming the long-term strategic goal of the public authorities for social stability in the Rostov border region. The study findings suggest that the main measures need to be aimed at finding ways to reduce the conflict potential of migration; increase the openness of the labor market and reduce the level of unemployment; and improve the security measures, taking into account the proximity to state border.
\end{abstract}

UDC Classification: 316.4; DOI: http://dx.doi.org/10.12955/cbup.v6.1243

Keywords: border region, social well-being of the population, humanitarian challenges.

\section{Introduction}

The Rostov region, located in the southern part of the East European Plain and the North Caucasus region, occupies a vast area of $100800 \mathrm{~km}^{2}$ in the river basin of the Lower Don. It is a part of the Southern Federal District, the center of which is Rostov-on-Don, a city with a million-plus population. The region has a state border with Ukraine, the length of which is $660 \mathrm{~km}$.

The specific nature of border regions requires a special approach for their development. The researchers attribute these areas with a lower level of social and economic development than in the deeper regions. Slightly less than half of the regions with the repressive type of development and the majority of deeply repressed regions of Russia are located on the border territories (Badarchi \& Dabiev, 2012). Humanitarian challenges, primarily related to the increase in migrant flows, the instability of the social and economic situation, and the intensifying social differentiation, have had an impact on society in the border lands. The consequences of this impact affect the social well-being of the population of the border region, creating sources of social tension. The aforementioned represents the need for an analysis of the main components of the population's social well-being in the border areas in terms of the humanitarian challenges. At the same time, this topic is particularly acute in regions with a geopolitical position that could characterize them as areas of increased risk. The Rostov region belongs to this type of region, having a common border with south-eastern regions of Ukraine. It has a status of the 'gate of the Caucasus'. These are the additional factors that expand frustrations among its population. In this regard, this article presents the results of a study into the social wellbeing, particularly, the humanitarian challenges of the Rostov people, who live in this border region of Russia.

Social well-being is an important factor affecting an individual's quality of life and attitude towards the main social structure. In terms of the humanitarian challenges, it becomes a 'litmus paper' of the societal status and substantially supplements the economic statistics. In the scientific literature, there are different views on the components of this social well-being (Morrow, 1999, Ryan \& Deci, 2000; Gorshkov at al., 2016; Volkov at al., 2013).

\section{Data and Methodology}

Taking into account the specifics of the studied region (its border location), the main research focused on the following variables:

\footnotetext{
${ }^{1}$ Institute of Sociology and Regional Studies, Southern Federal University, Russia, avserikov@ @fedu.ru

${ }^{2}$ Institute of Sociology and Regional Studies, Southern Federal University, Russia, abedrik@bk.ru

${ }^{3}$ Institute of Sociology and Regional Studies, Southern Federal University, Russia, panfilovajulia@mail.ru
} 
1. Common emotional and psychological state of the population of the border region;

2. Level of tension in the society by the inhabitants of the region;

3. Perceptual acuity of the problems that have a decisive impact on the quality of life and the social infrastructure in the settlement;

4. The personal security level, taking into account the proximity to the state border;

5. The interethnic relations and the effect migration has on it; and

6. The social well-being of the population in the labor market of the region in terms of the humanitarian challenges.

The analysis of the identified components of the social well-being required a preliminary description of its macrosocial context, which was related to the peculiarities of the geopolitical position of the region and the social and economic state.

Data were obtained from the Territorial Body of the Federal State Statistics Service (FSSS) (ROSSTAT, 2018) in the Rostov Region. The results of recent sociological research provided the basis for characterizing the local labor market as a potential deterrent for the social and professional mobility. These data were obtained from the South Russian branch of the Federal Research Sociological Center (FRSC) of the Russian Academy of Sciences.

\section{Results and Discussion}

There are several points to note about the ethnic composition of the population of the region and the flow of migrants. Apart from the numerical predominance of Russians, the region has historically evolved as a multicultural one. According to the Territorial Body of the FSSS of the Russian Federation in the Rostov region, today, about 150 ethnic groups live in the region. This number rises annually due to the expanding flow of migrants from the North Caucasus republics and from nearby abroad countries (Territorial Body of the FSSS in the Rostov Region). This has been caused by, on the one hand, the attractiveness of the region for migration and on the other, by its proximity to areas of local conflict. Altogether, this increases the burden on the social infrastructure of host settlements and creates sources of social tension, which makes the flow of migrants a serious challenge for the social stability of the studied region (Serikov, 2015).

A number of important features about the regional labor market are evident as part of the macrosocial context of the social well-being of the Rostov population. According to the official statistics of 20002017, the level of registered unemployment (according to the International Labour Organization (ILO) methodology) declined steadily from 15\% in 2000 to 5.3\% in 2017 (Territorial Body of the Federal State Statistics Service in the Rostov Region). This indicator slightly exceeded the level of unemployment in the country as a whole, though it was the lowest in the Southern Federal District at the time. Although the level of registered unemployment in the Rostov region, as a whole, showed no deviation from the 'all-Russian' indicators, the data of the South Russian branch of the FRSC of the Russian Academy of Sciences showed that almost half of the working population acknowledged the risk of job loss. Inequality in accessing jobs was consistently included in the three most identified inequalities. The work of Posukhova (2014) showed that $23 \%$ of the regional residents worked concurrently at several workplaces to improve their financial situation; $21 \%$ used any opportunity for one-time temporary benefits; and $19 \%$ of the respondents accepted overtime or part-time jobs. In the period of the social and economic situation instability, the labor market, as an indicator of the social well-being, increased its significance substantially.

The production and social infrastructure of the region were highly differentiated due to two main trends. The first is the deformation of some economic sectors that form the bases of survival for a number of settlements (mainly in the extractive industries). The second is the restructuring of the agrarian sector that was the basis for the rural economy, which slowed the development of the industrial and social infrastructure. As a result of these processes, a social and professional structure and a model of the labor market formed in each of the territories. There was a sharp polarization of the territories according to their power and economic, human, and cultural capital (Panfilova, 2017). The noted tendencies intensified social inequality, which represents one of the humanitarian challenges for the regions.

The social well-being of the population in the Rostov region showed general trends. The macrosocial changes influenced the state of the social well-being of the population in the border region. The results 
of the triennial measurements show that, since the 2015 year, the relative balance between positive and negative assessments of the daily emotional and psychological state remains the same. It repeats the all-Russian trends on the whole (Table 1). A sense of calm and balance dominated the responses consistently, apart from a minor decrease in 2016. The 2015 level reflects that of 2017. Therefore, the practices of forced social adaptation to life's complexity were widespread among the residents of the area in terms of contemporary challenges. However, coinciding with the period of social and economic instability in 2017 , every fifth respondent responded that general life was accompanied by apathy and indifference. This result was 5\% and $8 \%$ higher than for the previous two years. The reply from some of a depressive state is also confirmed by an increase in response of general anxiety, as compared with the decrease in the share of the most positive grades (compared to 2015). Nonetheless, more negative states ('I feel the irritation, anger, aggression') showed a slight decrease (from 19.1\% to 12.8\%).

Table 1: Distribution of the answers of the residents of the Rostov region to the question 'How would you describe your usual, everyday emotional and psychological state?'

\begin{tabular}{|l|c|c|c|}
\hline \multicolumn{1}{|c|}{ Answers } & $\mathbf{2 0 1 5}$ & $\mathbf{2 0 1 6}$ & $\mathbf{2 0 1 7}$ \\
\hline I feel an emotional lift & $10.2 \%$ & $4.1 \%$ & $9.0 \%$ \\
\hline I feel calm, balanced & $46.5 \%$ & $39.6 \%$ & $47.8 \%$ \\
\hline I am in a state of indifference, apathy & $15.3 \%$ & $12.3 \%$ & $20.0 \%$ \\
\hline I feel the alarm & $15.3 \%$ & $12.3 \%$ & $20.0 \%$ \\
\hline I feel the irritation, anger, aggression & $19.1 \%$ & $7.4 \%$ & $12.8 \%$ \\
\hline
\end{tabular}

Source: Authors

With regard to the level of tension in the society, Table 2 shows the results of the research. Possibly the specifics of the geopolitical position of the Rostov region impose a certain effect on the population's social well-being. According to a survey conducted by the Southern Federal University, the represented residents of the region noted an increase in tension more often than those of Russia as a whole (65.6\% and 52.2\%, respectively (Volkov et al., 2016)).

Table 2: Distribution of the answers of the residents of the Rostov region to the question 'Do you think the tension in our society is growing or decreasing?'

\begin{tabular}{|l|c|c|}
\multicolumn{1}{|c|}{ Answers } & Russia & $\begin{array}{c}\text { The Rostov } \\
\text { Region }\end{array}$ \\
\hline The tension in the society is significantly reduced & $4.3 \%$ & $3 \%$ \\
\hline The tension in the society is slightly reduced & $16.8 \%$ & $13.1 \%$ \\
\hline The tension increases slightly & $36.7 \%$ & $46.1 \%$ \\
\hline The tension significantly increases & $15.5 \%$ & $19.5 \%$ \\
\hline The situation in the society remains the same & $26.8 \%$ & $17.4 \%$ \\
\hline
\end{tabular}

Source: Volkov et al., 2016

The general well-being of a population is largely determined by a range of parameters that are related to problems experience by a person in daily life. As the scientists of the FRSC of the Russian Academy of Sciences emphasized, the problems noted by the population are the ones most relevant for showing the level of the socioeconomic development of the country and the region (Gorshkov at al., 2016). The results of the regional research show that the problems relating to the satisfaction of basic needs (food, health, housing conditions, and personal security level) were not on of greatest urgency for the residents of the region ('good' estimates for these needs ranged from $28.9 \%-48.6 \%$ and 'bad' estimates were within 12.6\%). The main troublesome areas were the quality of medical care and opportunities for recreation during vacation and leisure times (Table 3).

The financial problems were more common in the small towns and urban-type settlements where the residents often noted dissatisfaction with the housing conditions and dress status. There were also low assessments of health care quality (69.2\% in urban-type settlements), which is the reflection of problems in this sphere that have become particularly acute in small towns (Vyalykh, 2015). As for rural settlements, contrary to expectations, the overall degree of positive assessments was quite high. The quality of medicine $(36.8 \%)$, leisure $(33.3 \%)$, and recreation during the vacation $(39.3 \%)$ were among the most urgent problems considered by rural respondents. Meanwhile, the villagers were most satisfied with life in general (only $1.9 \%$ noted 'bad' as the option). 


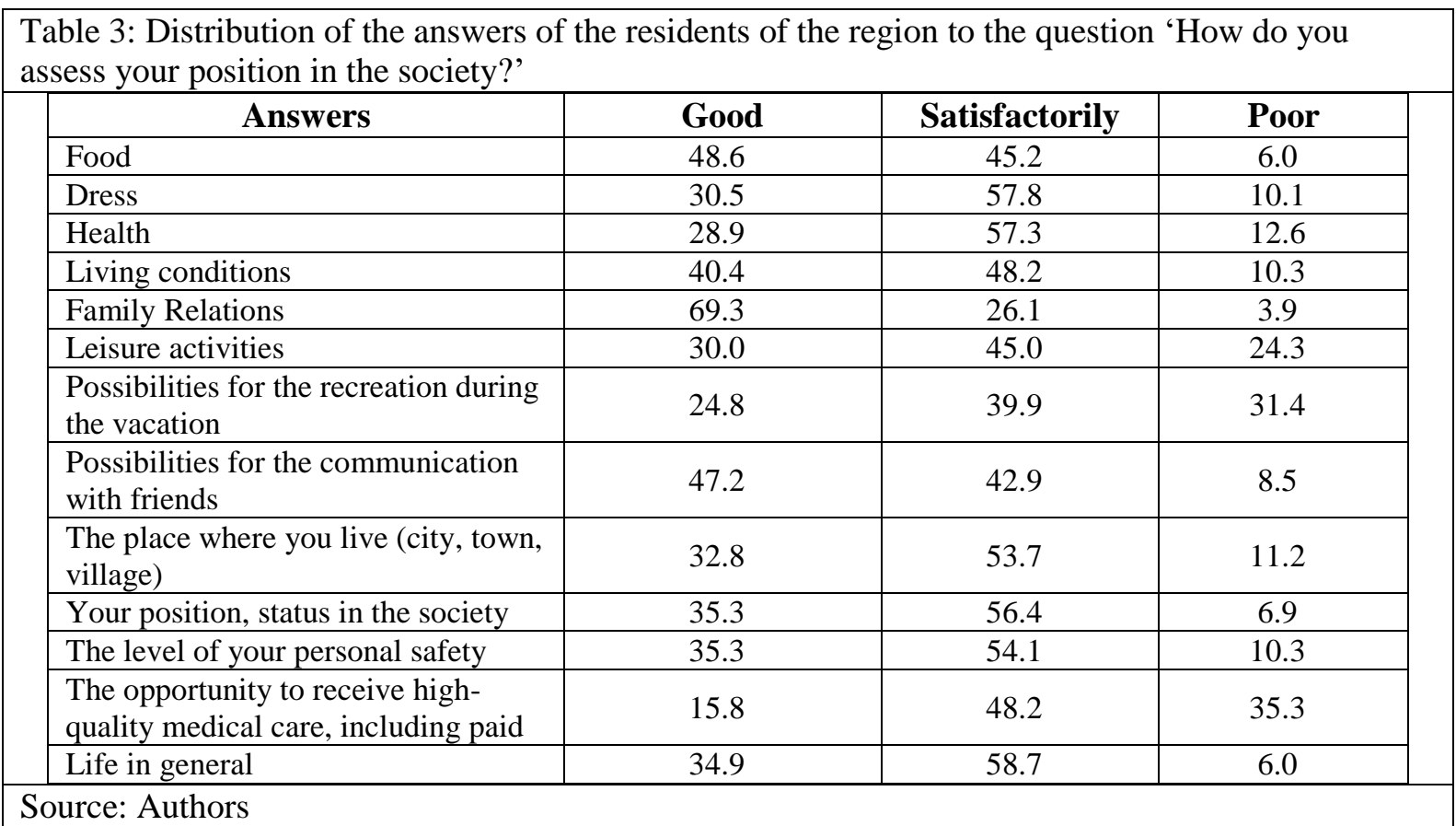

Personal security was estimated for the population of the border region. The concept of a 'border region' implies that the territory included in it is experiencing a significant impact on the state border. This somehow affects the assessments of the level of personal security. In the case of the Rostov region, the situation is complicated by the proximity to regions of the North Caucasus. In the terms of the events in Syria, the threat of radical Islamic spread has increased. However, the empirical measurements of the last three years show that personal security remains a sphere where the population of the region considers there has been significant improvements $(49 \%-56 \%)$; in comparison with the all-Russian indicators the level of positive attitudes was almost 10 points higher among the inhabitants of the region (Volkov and Serikov, 2015; 2017). This result reflects the important work of state institutions in this area in the context of the humanitarian challenges. Nevertheless, the level of anxiety about personal safety shows an increase with the complexity of territory infrastructure (7.7\% in rural areas and $15.5 \%$ in the regional center).

The assessment of the scope of the interethnic relations was an important component of the social well-being of the population of a multi-ethnic region. The results of the research by the scientists of Southern Federal University (Volkov et al., 2016) show that, despite some distance, the nature of the interaction between the ethnic groups remained calm (Table 4).

\begin{tabular}{|c|c|}
\hline Answers & $\%$ \\
\hline $\begin{array}{l}\text { Relations are good, people do not pay attention to } \\
\text { each other's nationality }\end{array}$ & $30.8 \%$ \\
\hline $\begin{array}{l}\text { Relations are calm, but people communicate } \\
\text { mainly with the representatives of their nationality }\end{array}$ & $41.5 \%$ \\
\hline There is some tension in the relationships & $11.3 \%$ \\
\hline There are national conflicts & $5.7 \%$ \\
\hline Not sure & $10.7 \%$ \\
\hline Source: Volkov et al., 2016 & \\
\hline
\end{tabular}

However, concerning the ethnic flows of labor migration, as a factor of interethnic relations, the estimates of the region's population were more polarized. The researchers of Southern Federal University recognized migration to the Rostov region as a distinct ethnic character. Their research results showed differentiation of the respondents' answers. One group implied migration had no influence on interethnic relations $(30.8 \%)$ while others indicated varying levels negative consequences (58.5\%). It is also noted that $10.7 \%$ of the respondents found it difficult to provide a definite 
assessment. These residents were considered a 'risk group' since, in case of a deteriorating situation, they would likely join the group with negative attitudes (Volkov et al., 2016). Heightened tension occurs primarily in places of concentrated migrant settlement (the area in the southeast of the region with favorable landscape and climatic conditions for economic activity). In 2014, a more complicated situation arose due to migrant influx from the southeast of Ukraine. Experts emphasized that the receiving environment could not absorb the migration without distress to local communities caused by the integration of an incoming population. The competition for economic, labor, and land resources in a situation of largely low employment in the rural areas led to accumulated discontent among the local population and worsening of the general social and economic well-being. The high level of migrant group cohesion and their isolation and behavioral norms amplified hostilities in the host community (Serikov \& Bedrik, 2017). Thus, the labor migration to the region has a certain conflict potential. While the interethnic relations, as a component of social well-being, is viewed positively by the general population of the Rostov region, the expanding migration flows is a factor of increasing general anxiety.

For the social well-being of those within the regional labor market, in terms of humanitarian challenges, the following trends were observed. The position and opportunities in the regional labor market is an important component of the social well-being of the residents in the border region in terms of dealing with economic instability, internal and external migration, and increased competition of the ethnic groups for certain niches within the employment areas. According to the data of the South Russia Branch of the FRSC of the Russian Academy of Sciences, the degree of positive ratings in this sphere was quite low. Apart from extreme negative gradings (below 11\%), the majority of the respondents favorably viewed the chances for successful employment $(56.4 \%)$ and opportunities for the professional fulfillment (52.4\%). These indicators had not changed over the previous five years. The comparison of the spheres of potential employment indicated that the most prestigious social and professional positions in the region are difficult to obtain. The monitoring of the regional vacancy market showed that the vacancies related to the administrative personnel, banking and financial workers, and information technology rarely appear for general access. The territorial deformation of the regional labor market, mentioned above, affects the assessment of the career opportunities. The absence of a variety of areas of employment in rural areas and small towns, caused by a small set of industries, significantly narrows professional choice. At the same time, the opportunities for obtaining additional knowledge were viewed positively by a third of the respondents (33.9\% as 'good'). This is most likely due to the rather high level of the educational infrastructure development in the studied region.

\section{Conclusion}

The results of this study show that the frontier position of the Rostov region influences the main components of the population's social well-being. The humanitarian challenges faced by Russian regions in recent years, i.e., the increase of migrants, socio-economic instability, and social polarization, are experienced more so by the residents of the border area, subject to a complex geopolitical situation. This situation affects the nature of social well-being in the following way. A number of important conclusions can be drawn. First, the border area, in most cases, becomes an area of slow economic development. The Rostov region belongs to the type of region having a rate of development below the national average. As a consequence, a slow economy affects opportunities for material well-being of several population groups and in the regional labor market, creates tension, which is a destructive factor for social well-being. Second, the additional burden on social and domestic infrastructure and the local labor market caused by the external and internal migrants is adversely perceived by the host population. This burden becomes a factor of expanding frustration. Such a trend is especially observed in small towns and rural settlements, which were the least favorable positions in the territorial differentiation because of low incomes, lack of professional fulfillment and opportunities for human capital, and problems with social services. As a result, the level of migrant phobia has significantly increased with the migrant laborers considered potential carriers of social risks and that almost any domestic conflict is deemed interethnic related. Third, the proximity of local sources of conflict causes a higher level of tension in the border region than in Russia as a whole. The analysis of the general emotional and psychological state of the population showed a prevalence of residents who felt calm and balanced in general life. On the one hand, the 
results showed that a high adaptive potential of the population in terms of challenges, and on the other hand, it indicated their satisfaction with personal security, as evidenced by the high assessments of the state institutions' activities in this field. Finally, to improve social stability, it is recommended that public authorities of the Rostov region instill a long-term strategy to increase the overall level of social well-being of the population. First and foremost, to mitigate the potential conflict, due to migrant influx, include ways that increase labor market access, reduce unemployment, and further improve security measures in terms of the proximity to the state border.

\section{Acknowledgments}

The article was supported by an internal grant of the SFedU No. VnGr-07/2017-22 'Transconflict Regions as a Phenomenon of the Geopolitical Competition: Social Risks and Resources of Adaptation to Humanitarian Challenges'.

\section{References}

Badarchi, K.B., \& Dabiev D.F. (2012). Tipologicheskiy analiz prigranichnykh regionov Rossii po urovnyu sotsial'noekonomicheskogo razvitiya (na primere Respubliki Tyva) [Typological analysis of Russia's border regions by the level of socioeconomic development (case study of the Republic of Tuva)]. Studies on Russian Economic Development, vol. 23, no. 2, s. $172-180$

Gorshkov, M.K., Tikhonova, N.E. (Eds.) (2016). Rossiyskoye obshchestvo i vyzovy vremeni [Russian society and challenges of the time]. Moscow: Ves Mir Publishers, 424 s.

Morrow, V. (1999). Conceptualising Social Capital in Relation to the Well-Being of Children and Young People: A Critical Review. The Sociological Review, vol. 47, no. 4, s. 744-765.

Panfilova, Y.S. (2017). Macrosocial factors of inter-generational mobility of the population in the Rostov region. State and municipal management. Scholar notes, no. 1, s. 250-254.

Posukhova, O.Y. (2014). Endogennyye faktory sotsial'noy mobil'nosti v Rostovskoy oblasti [Endogenous factors of social mobility in the Rostov region]. Power, no. 9, s. 94-99.

Posukhova, O.Y.\& Serikov, A.V. (2017). Rossiyskaya natsional'naya politika v otsenke i vospriyatii naseleniya YuzhnoRossiyskogo regiona [Russian national policy in assessment and perception of South-Russian region population]. Power, no. 8, s. 143-150.

ROSTOVSTAT (2018). Territorial Body of the Federal State Statistics Service in the Rostov Region. Retrieved from http://rostov.gks.ru/.

Ryan, R.M., \& Deci, E.L. (2000). Self-determination theory and the facilitation of intrinsic motivation, social development, and well-being. American Psychologist, no. 55(1), s. 68-78.

Serikov, A.V. (2015). Mezhetnicheskiye otnosheniya mezhdu migrantami i prinimayushchim naseleniyem (na primere Rostovskoy oblasti) [The international relations between migrants and the accepting population (on the example of the Rostov region)]. V Sukharevsky readings: "Regional differentiation and consolidation of social space of Russia: realities and new calls". Saransk, Russian Federation, 2015.Saransk: Scientific center of social and economic monitoring, 2015. ISBN: 978-5-906046-16-1. S. 419-422.

Serikov, A.V., \& Bedrik A.V. (2017). Upravleniye mezhnatsional'nymi otnosheniyami i migratsionnymi protsessami v yuzhnorossiyskom regione: institutsional'nyy profil' i perspektivy povysheniya effektivnosti [Management of international relations and migration processes in the southern Russian region: institutional profile and prospects for improving efficiency]. State and municipal management. Scholar notes, no. 4, s. 226-230.

Volkov, U.G., Barkov, F.A., Posukhova, O.Yu., Serikov, A.V., \& Chernous, V.V. (2013). Sotsial'noye samochuvstviye i sotsial'noye neravenstvo v Rostovskoy oblasti [Social well-being and social inequality in the Rostov region]. Humanitarians of the South of Russia, no. 4, s. 12-32.

Volkov, Y.G., Denisova, G.S., \& Lubskiy, A.V. (2016). Otsenka naseleniya yuzhnorusskogo kharaktera etnicheskikh otnosheniy pri realizatsii strategii natsional'noy strategii [Assessment of the population of the south Russian character of ethnic relations during the realization of the national strategy policy]. "P.O.I.S.K." (Policy. Social Science. Art. Sociology. Culture), no. 6 (59), s. 117-129.

Vyalykh, N.A. (2015). Faktory vosproizvodstva sotsial'nogo neravenstva v sfere potrebleniya meditsinskikh uslug [Factors of social inequality reproduction in the sphere of medical services consumption]. Sociological Studies, no 11 (379), s. 126-132.

Volkov, Y.G. (2015). Sotsiologicheskaya diagnostika kak analiticheskaya konstruktsiya [Sociological diagnosis as analytic construct]. Sociological Studies, no. 3 (371), s. 3-11.

Volkov, Y.G. (2017). Solidarnaya aktivnost' v rossiyskom obshchestve kreativnyye praktiki [Solidary activity in Russian society: creative practice]. Sociological Studies, no. 2, s. 41-48. 